\title{
Structural Fire Protection of Steel Structures in Arctic Conditions
}

\author{
Marina Gravit (1) and Daria Shabunina *(D)
}

Citation: Gravit, M.; Shabunina, D. Structural Fire Protection of Steel Structures in Arctic Conditions.

Buildings 2021, 11, 499.

https://doi.org/10.3390/

buildings11110499

Academic Editor: Nerio Tullini

Received: 17 September 2021

Accepted: 20 October 2021

Published: 22 October 202

Publisher's Note: MDPI stays neutral with regard to jurisdictional claims in published maps and institutional affiliations.

Copyright: (c) 2021 by the authors. Licensee MDPI, Basel, Switzerland. This article is an open access article distributed under the terms and conditions of the Creative Commons Attribution (CC BY) license (https:// creativecommons.org/licenses/by/ $4.0 /)$
Civil Engineering Institute, Peter the Great St. Petersburg Polytechnic University, 195251 St. Petersburg, Russia; marina.gravit@mail.ru

* Correspondence: d.shabunina00@gmail.com

Abstract: Most structures in the Arctic and Antarctic for oil and gas production are offshore stations, tankers, modules, steel supporting, and enclosing structures, which need to be protected against both cryogenic spills and fire exposure. Oil and gas industry facilities have products of high flammability and explosiveness, which in the case of ignition make it possible to develop a fire along the hydrocarbon curve, accompanied by a sharp jump in temperature and the formation of excessive pressure. This article discusses possible structural fire protection for metal structures in the Arctic region. Three different structural fireproofing materials are presented using super-thin basalt fiber (STBF) as an example. Tests of steel structures with fire protection are demonstrated, as a result of which the time from the beginning of cryogenic exposure to the limit state of samples is determined, and after the time from the beginning of thermal exposure to the limit state of samples under the hydrocarbon temperature regime is determined. An assessment of various flame retardants with values up to $120 \mathrm{~min}$, which can be used in arctic climate conditions, was carried out. It was found that the most effective coatings are materials prepared on the basis of STBF.

Keywords: steel structure; oil and gas facility; super-thin basalt fiber (STBF); hydrocarbon fire; endothermic mat; cryogenic and fire exposure

\section{Introduction}

The Arctic climate is the most severe with absolute minimum winter temperatures from $-54{ }^{\circ} \mathrm{C}$ to $-71^{\circ} \mathrm{C}$ [1]. Buildings and structures in the Arctic and Antarctic are Arctic stations and plants for the production, refining, and transportation of products of the oil and gas facility, the steel load-bearing and enclosing structures of which need to be protected with special materials, in particular fire retardants to increase their fire resistance limits, also after the filling of cryogenic liquid, such as liquid natural gas (LNG) [2-4]. The ISO 20088-1:2016 [5], ISO 20088-2:2020 [6], and ISO 20088-3:2018 [7] series of standards regulate the effects of cryogenic liquid (simulation of liquefied hydrocarbon spills) on fire protection on steel structures. Further, the structure with fire protection is tested according to UL 1709 [8] or EN R 1362-2 (EN 1363-2:1999) [9,10] for the impact of a hydrocarbon fire regime (unambiguous requirements for the fire resistance limits of structures to the impact of hydrocarbon fire regime are presented only for structures of drilling platforms and offshore installations) [11]. There are precedents of fires at the stations. For example, the world's largest catastrophe at the Piper Alpha platform in the North Sea on 6 July 1988, resulted in a series of explosions in the main oil and gas pipelines [12,13]. Deepwater Horizon, which took place on 20 April 2010, is one of the biggest technological disasters resulting in human losses and destruction as well as a negative impact on the environment [14]. Fires also occur at Arctic stations, the bearing elements of which are steel structures. For example, in 2012 a fire destroyed the Antarctic research station Comandante Ferraz, located on King George Island in Antarctica [15].

In arctic conditions, the following requirements are presented for the fire protection of steel structures: saving reliability (operability) in the Arctic climate for at least 10 years, and 
"dry" installation without liquid phase, resistance to extreme effects in the form of liquid hydrocarbon spills, with their further ignition and the development of a hydrocarbon fire mode [16-26].

Optimal solutions for the protection of steel structures in fires were considered in [27] with the example of intumescent coatings. In [28], the effect of the main components of intumescent coating on the flame retardant properties was studied. An important component of intumescent coating is the binder, which has the following main functions: elasticity, hardness, and durability. On the whole, the listed physical and chemical characteristics allow to obtain a quality, defect-free, durable flame retardant coating. One of the important aspects of intumescent coating is its relative water solubility [29]. Thus, when using a surface exposed to water or a humid environment, the effectiveness of base protection is reduced due to the possible washout of the compounds responsible for bloating. In [30], I-beam steel columns with a plaster fireproofing coating were tested under hydrocarbon fire conditions with a fire protection efficiency of $120 \mathrm{~min}$, but "wet" application under Arctic conditions is impossible. A numerical evaluation of the effectiveness of different configurations of passive fire protection (PFP) layers in marine topsides structures exposed to localized fires is presented in [31]. The paper describes the use of a simplified methodology in evaluating the thermo-mechanical behavior of an offshore structure under high temperatures, taking into account the presence of a PFP layer. A series of tensile tests of two types of mineral wool materials at room temperature and at high temperatures in fire conditions is demonstrated in [32]. The mechanical properties were verified using modified methods and a database was created to apply a series of nonlinear structural and thermal finite-element analyses of the PFP bulkhead marine system.

The scheme of means and methods of fire protection of steel structures is shown in Figure 1, demonstrating that the most preferable means of fire protection in the Arctic climate is the application of structural fire protection, the main advantage of which is the "dry" installation and high fire resistance.

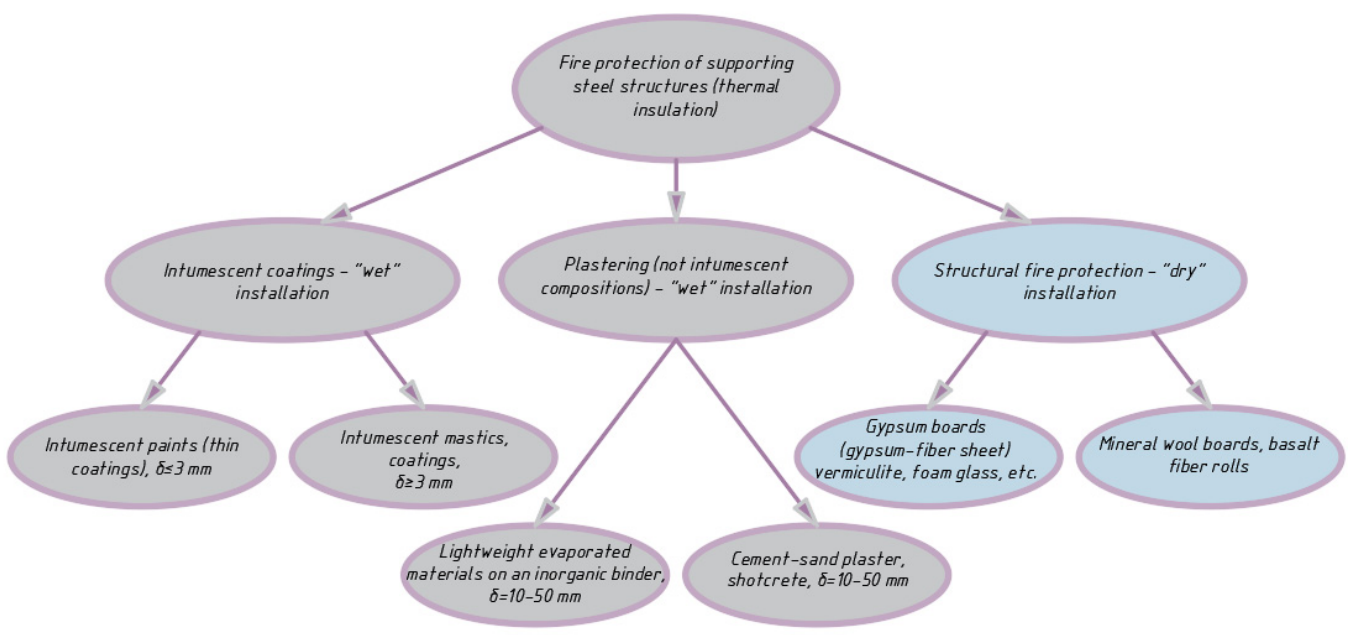

Figure 1. Means and methods of fire protection of steel structures.

A prospective basis for thermal insulation materials and products is super-thin basalt fibers (STBF) made exclusively from basalts without admixtures of other minerals [33]. Thermal insulation products based on STBF practically do not have an alternative in the energy shipbuilding and aircraft industry, in construction, of which the main area of application is to increase the fire resistance of structures. Due to thermal properties, durability, non-combustibility, resistance to low and high temperatures and vibrations, environmental friendliness, fire resistance, and low hygroscopicity, thermal insulation products based on STBF are much superior to their analogues. Thus, in the Arctic conditions, it is more preferable to use thermal insulating materials with mineral components (Table 1). 
Table 1. Comparison of the characteristics of different types of insulation wool.

\begin{tabular}{|c|c|c|c|c|}
\hline Name of Parameters & Slag Wool & Glass Wool & TBF & STBF \\
\hline $\begin{array}{l}\text { Limit temperature } \\
\text { application, }{ }^{\circ} \mathrm{C}\end{array}$ & up to 250 & $\begin{array}{l}\text { from }-60 \text { to } \\
\quad+450\end{array}$ & $\begin{array}{l}\text { from }-190 \text { to } \\
\quad+700\end{array}$ & $\begin{array}{l}\text { from }-190 \text { to } \\
\quad+1000\end{array}$ \\
\hline Sintering temperature, ${ }^{\circ} \mathrm{C}$ & $250-300$ & $450-500$ & $700-1000$ & $1100-1500$ \\
\hline $\begin{array}{l}\text { Average fiber diameter, } \\
\mu \mathrm{m}\end{array}$ & 4 to 12 & 4 to 12 & 5 to 15 & 1 to 3 \\
\hline Length of fibers, $\mathrm{mm}$ & 16 & $15-50$ & $20-50$ & $50-70$ \\
\hline $\begin{array}{l}\text { Sorption humidification } \\
\text { per } 24 \mathrm{~h} .(\max ), \%\end{array}$ & 1.9 & 1.7 & 0.035 & 0.02 \\
\hline Using the binder & yes & yes & yes & no \\
\hline Presence of binder, $\%$ & 2.5 to 10 & 2.5 to 10 & 2.5 to 10 & - \\
\hline $\begin{array}{l}\text { Thermal conductivity } \\
\text { coefficient, } \mathrm{W} /(\mathrm{m} \cdot \mathrm{K})\end{array}$ & $0.46-0.48$ & $0.038-0.046$ & $0.038-0.046$ & $0.035-0.046$ \\
\hline Heat capacity, $\mathrm{J} / \mathrm{kg} \cdot \mathrm{K}$ & 1000 & 1050 & $500-800$ & $800-1000$ \\
\hline Density, $\mathrm{kg} / \mathrm{m}^{3}$ & $75-400$ & $10-130$ & $26-36$ & $18-25$ \\
\hline $\begin{array}{l}\text { Sound absorption } \\
\text { coefficient }\end{array}$ & 0.75 to 0.82 & 0.8 to 92 & 0.8 to 95 & 0.95 to 99 \\
\hline Vibration resistance & no & no & no & yes \\
\hline
\end{tabular}

Consider the products of structural fire protection on the basis of STBF of two Russian manufacturers LLC "PROMIZOL" and LLC "BST" and international company "3M". All these flame retardant coatings belong to KM0 class [34] and are complex composites in the form of bendable sheets (rolls). "PROMISOL-MIKS PROPLATE-50-K" and "BSTMAT" consist of a combination of noncombustible materials from STBF, glass wool, silica fabrics, and attachment straps on their bases, while " $3 \mathrm{M}$ Interam" represents a flexible mat with basalt fiber and endothermic components, including a fireproof waterproof sealant, aluminum tape, and steel tape bandage. The main advantages of the considered fire-retardant coatings are: "dry" installation on various steel structures of buildings and constructions, corrosion resistance, easiness of installation on structures of complex shape, and the possibility of long-term operation in severe conditions.

The purpose of this article is to study structural protection on the basis of STBF under operating conditions in the Arctic climate. Fire retardant materials "PROMISOL-MIX PROPLEIT-50-K" (sample No. 1) and "BST-MAT" (sample No. 2) during fire test under a hydrocarbon temperature regime and fire retardant "3M Interam" (sample No. 3.1 and sample No. 3.2) during cryogenic exposure and during a subsequent fire test under a hydrocarbon fire regime were considered.

\section{Materials and Methods}

Experimental samples were tested according to $[35,36]$ under the condition of creating a hydrocarbon temperature regime in the fire chamber of the furnace according to [10], characterized by the following dependence (1):

$$
T-T_{0}=1080 \cdot\left(1-0.325 \cdot e^{-0.167 t}-0.675 \cdot e^{-2.5 t}\right)
$$

where $T$ means the temperature inside the furnace in ${ }^{\circ} \mathrm{C}$, corresponding to the relevant time $\mathrm{t} ; T_{0}$ is the temperature in ${ }^{\circ} \mathrm{C}$ inside the furnace prior to the start of heat impact; and $t$ is the time in min from the start of the test. 
The limiting state during fire testing under the hydrocarbon temperature regime is assumed to be when the metal of the test sample reaches the critical temperature equal to $500{ }^{\circ} \mathrm{C}$. The conditions of cryogenic tests were established according to [5-7], and the conditions of fire tests were established according to [35].

The humidity of the fire retardant was dynamically balanced with the environment with a relative humidity of $(60 \pm 15) \%$ at a temperature of $(20 \pm 10)^{\circ} \mathrm{C}$.

For samples No. 1 and No. 2, the temperature in the furnace's firing chamber was measured by thermocouples, installed by caulking in the amount of three pieces in the average cross-section of the samples on the I-beam wall and on the inner surface of the flanges in accordance with [36], and for samples No. 3.1 and No. 3.2 six thermocouples were installed, three main and three duplicating, symmetrically to the main.

\subsection{Experiment No. 1}

Sample No. 1 was a steel column of I-shaped cross-section No. 20B1 [37] with a height of $1700 \mathrm{~mm}$ and a section ratio of $294 \mathrm{~mm}^{-1}$ [38]. The thickness of the protective layer on the prototype was $50 \mathrm{~mm}$. The test was carried out in the VNIIPO of the Ministry of Emergency Situations in Russia.

Sample No. 1 was placed in the fire chamber of the furnace and subjected to four-sided heat exposure without static load until the limit state of the sample. The temperature in the fire chamber was created by the hydrocarbon fire regime according to (1) and was measured with furnace thermocouples in five locations.

\subsection{Experiment No. 2}

Sample No. 2 was a steel column of I-shaped cross-section No. 50B2 [37] with a height of $1700 \mathrm{~mm}$ and a section ratio of $172 \mathrm{~mm}^{-1}$ [38]. The thickness of the protective layer on the prototype was $20 \mathrm{~mm}$. The test was carried out in the testing laboratory «POZH-AUDIT».

Before the tests, measurements were made of the actual thickness of the fire-retardant coating applied to the sample. The thickness of the coating was measured at 36 points along the perimeter of the heated surface, in steps of $500 \mathrm{~mm}$ along the height of the sample.

Sample No. 2 was placed in the fire chamber of the furnace and subjected to foursided heat exposure without static load. In the fire chamber of the furnace, a hydrocarbon temperature regime was created according to (1).

\subsection{Experiment No. 3}

Two samples were examined for the experiment No. 3. Sample No. 3.1 was a steel column of I-shaped cross-section No. 50B2 [37] with a section ratio of $170 \mathrm{~mm}^{-1}$ [38], with flame-retardant coating with the following composition: endothermic $3 \mathrm{M}$ Interam ${ }^{\circledR}$ E-Mat ${ }^{\circledR}$ in 2 layers with a total thickness of $20.6 \mathrm{~mm}$, waterproof flame retardant sealant 3M 3000WT, 3M Aluminum tape 425/437 and steel tape bandage. Sample No. 3.2 was a steel column of I-shaped cross-section No. 50B2 [37] with a section ratio of $170 \mathrm{~mm}^{-1}$ [38] aand flame-retardant coating of the following composition: endothermic $3 \mathrm{M}$ Interam ${ }^{\circledR}$ E-Mat ${ }^{\circledR}$ in 3 layers with a total thickness of $30.9 \mathrm{~mm}$, waterproof flame retardant sealant $3 \mathrm{M} 3000 \mathrm{WT}$, 3M Aluminum tape 425/437, and steel tape bandage. The test was conducted at the test center «Ognestoykost».

The tests of the samples were carried out in two stages: the stage of cryogenic exposure and the stage of thermal exposure under hydrocarbon fire conditions according to (1). Both test stages were conducted sequentially on the same day.

Test methods for the different character of cryogenic liquid hydrocarbon emissions are assigned in the ISO 20088 series of standards [5-7], where liquid nitrogen is used as a liquid hydrocarbon analogue, since it has a lower boiling point than LNG or liquid oxygen and is not flammable. 
ISO 20088-1 [5] includes complete immersion of the test sample in a cryogenic liquid. The limiting temperature drop is defined as the difference between the ambient temperature and the limiting temperature for the steel. The sample meets the requirements provided that the temperature does not exceed the limit temperature.

The test to determine the time of reaching the critical state under cryogenic exposure was carried out according to the regulations of ISO 20088-1 [5] with a decrease in the limiting temperature to $-50{ }^{\circ} \mathrm{C}$ as requested by the technical customer. The duration of exposure to liquid nitrogen on the flame retardant system was $60 \mathrm{~min}$. After the specified time, the cryogenic exposure of the flame retardant sample was stopped.

To conduct the cryogenic test, a tank made of polystyrene foam with dimensions of at least $700 \mathrm{~mm} \times 180 \mathrm{~mm} \times 80 \mathrm{~mm}$ (Figure 2) was glued to the surface of the fireproof mat strictly in the center of the I-beam flange using a flame-retardant sealant. The area of the tank overlapped the attachment points of thermocouples on the beam flange. Then, at least $3.5 \mathrm{~L}$ of liquid nitrogen was poured into the tank, and to reduce the rate of vaporization, the tank was covered with a sheet of polystyrene foam $50 \mathrm{~mm}$ thick from above.

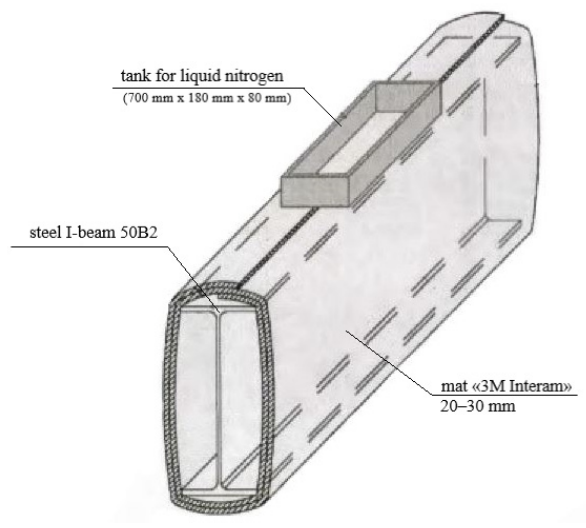

(a)

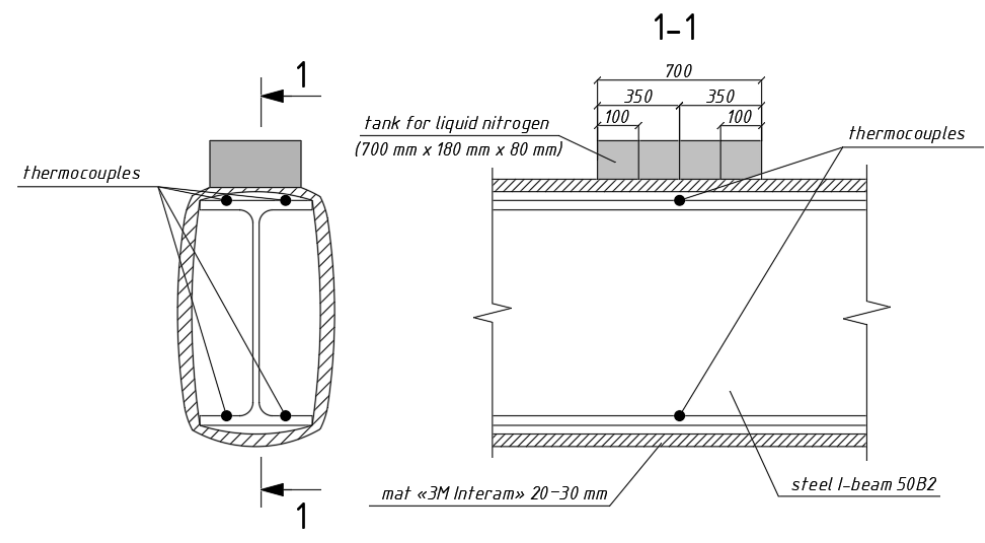

(b)

Figure 2. (a) Schematic diagram of the fire protection coating assembly; (b) Section of the fire protection coating assembly with thermocouple location.

After the end of exposure to liquid nitrogen on the flame retardant systems of samples No. 3.1 and No. 3.2, a tank of polystyrene foam and sealant residues were removed from its surface. After these measures, to conduct fire tests, the samples were placed in a test furnace, in which a hydrocarbon temperature regime was maintained, characterized by dependence (1).

\section{Results}

\subsection{The Results of Experiment No. 1}

According to the test results it was found that sample No. 1 of $50 \mathrm{~mm}$ thickness provides fire protection efficiency under conditions of exposure to hydrocarbon combustion regime for $90 \mathrm{~min}$ for steel column of I-beam section of profile No.20B1 of $1700 \mathrm{~mm}$ height with a section ratio of $294 \mathrm{~mm}^{-1}$. During the tests, no visible changes in the external state of the sample were recorded: there were no cracks, fissures, damage, or charring of the surface, and there was no smoke emission (Figure 3). Belts and steel straps were not subjected to changes. The experiment was stopped at $95 \mathrm{~min}$ after reaching the critical temperature on the sample. As a critical temperature, $500{ }^{\circ} \mathrm{C}$ is taken, the average value of measurements of thermocouples, installed by caulking in the amount of three pieces in the average cross-section of the samples on the I-beam wall and on the inner surface of the flanges. 


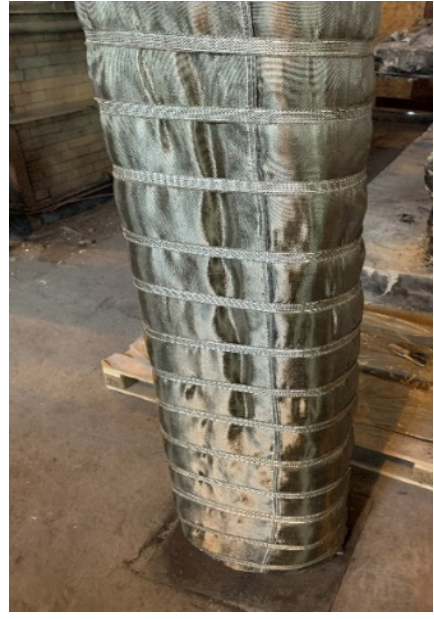

(a)

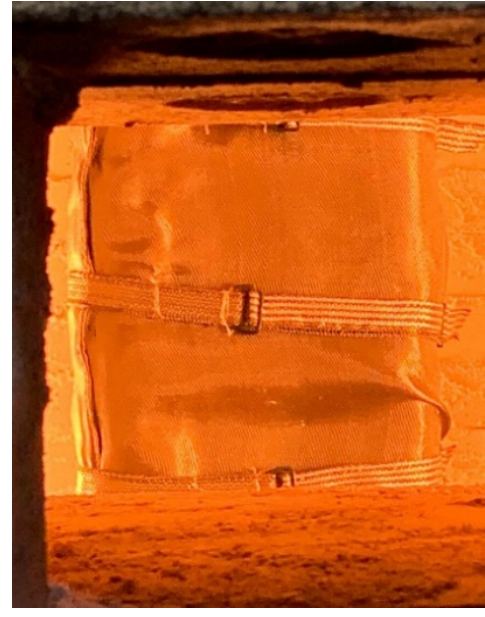

(b)

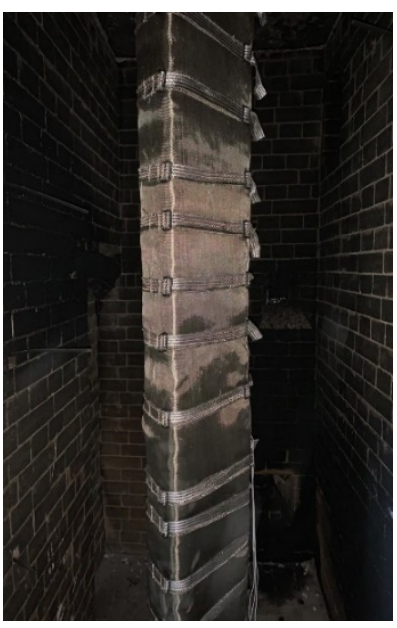

(c)

Figure 3. (a) Sample No. 1 before the test; (b) during the test; (c) after the test.

\subsection{The Results of Experiment No. 2}

According to the test results, it was found that sample No. 2 of $20 \mathrm{~mm}$ thickness provides fire protection efficiency under conditions of exposure to a hydrocarbon combustion regime for $90 \mathrm{~min}$ for steel column of I-beam section of profile No.50B2 of $1700 \mathrm{~mm}$ height with a section ratio of $172 \mathrm{~mm}^{-1}$. At the end of the experiment, burning of aluminum foil and slight embrittlement were observed on the surface. The steel ties did not present any changes. The experiment was stopped at $92 \mathrm{~min}$ after reaching the critical temperature on the sample (Figure 4).

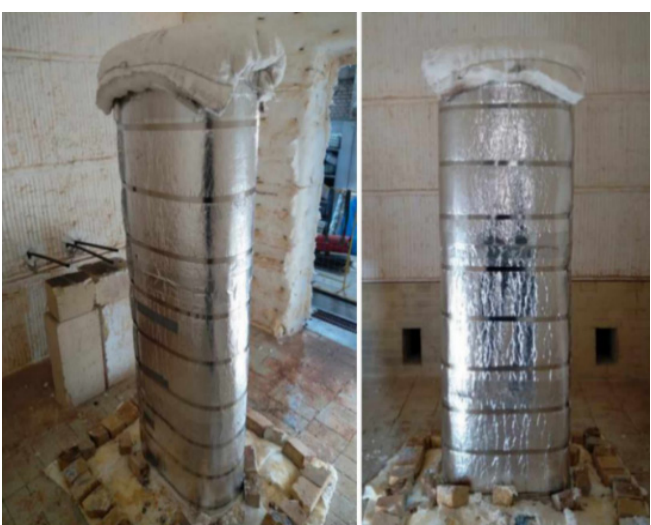

(a)
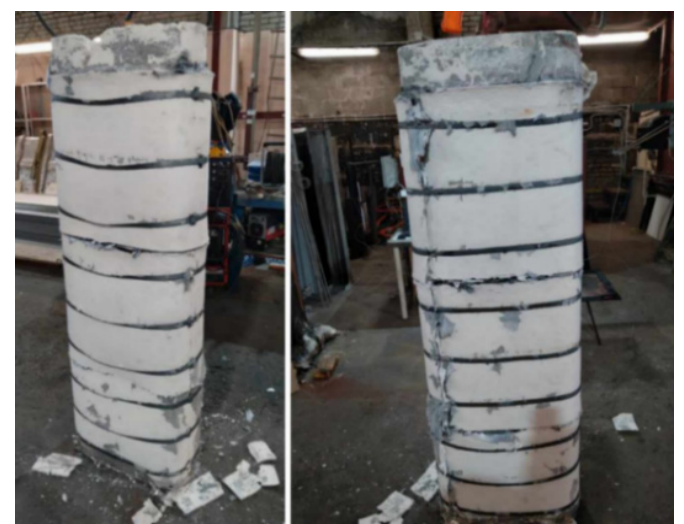

(b)

Figure 4. (a) Sample No. 2 before the test; (b) after the test.

\subsection{The Results of Experiment No. 3}

According to the test results, sample No. 3.1 of $20.6 \mathrm{~mm}$ dry layer thickness applied to a steel column of the I-beam section of profile No.50B2 with a section ratio of $170 \mathrm{~mm}^{-1}$ provides a time of reaching the critical temperature $-50{ }^{\circ} \mathrm{C}$ in the sample during $60 \mathrm{~min}$ in the mode of cryogenic influence of liquid nitrogen vapor, and a subsequent time of reaching critical temperature $500{ }^{\circ} \mathrm{C}$ in the sample during $90 \mathrm{~min}$ in the hydrocarbon combustion mode.

According to the test results, sample No. 3.2 of $30.9 \mathrm{~mm}$ dry layer thickness applied to a steel column of the I-beam section of profile No.50B2 with a section ratio of $170 \mathrm{~mm}^{-1}$ provides a time of reaching critical temperature $-50{ }^{\circ} \mathrm{C}$ in the sample during $60 \mathrm{~min}$ in the mode of cryogenic influence of liquid nitrogen vapor, and a subsequent time of reaching 
critical temperature $500{ }^{\circ} \mathrm{C}$ in the sample during $90 \mathrm{~min}$ in the hydrocarbon combustion mode.

Cryogenic test on the flame retardant systems of samples No. 3.1 and No. 3.2 showed that $1 \mathrm{~h}$ exposure to liquid nitrogen does not significantly reduce the surface temperature of the protected metal. In the case of the two-layer system (sample No. 3.1), the temperature decreases by $10-15^{\circ} \mathrm{C}$ from the initial temperature. In the case of the three-layer system (sample No. 3.2), no change in the temperature of the metal was recorded. Immediately after the complete evaporation of liquid nitrogen from the surface of the samples, at least 10 hammer blows were made, as a result of which the fire-retardant systems did not crack, split, or delaminate (Figure 5).

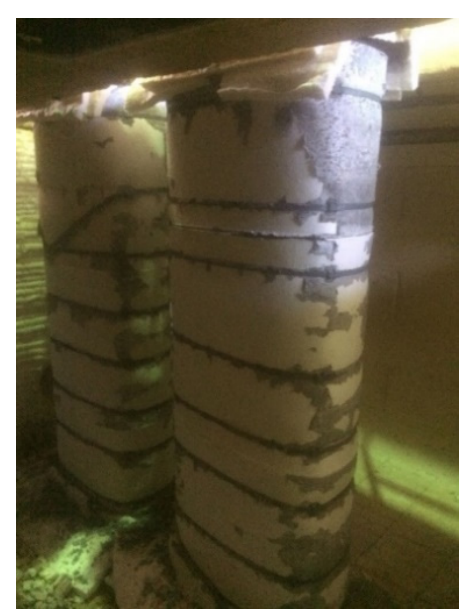

(a)

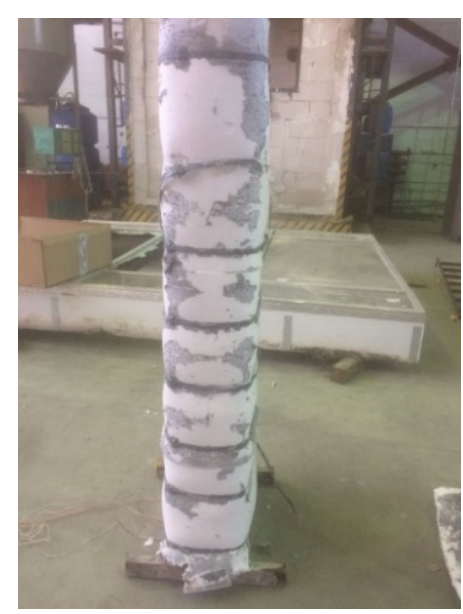

(b)

Figure 5. (a) Samples No. 3.1 and No. 3.2 during fire tests; (b) after all tests.

\section{Discussion}

Sample No. 3.1 with a dry layer thickness of $20.6 \mathrm{~mm}$ and a section ratio of $170 \mathrm{~nm}^{-1}$ after cryogenic testing for $60 \mathrm{~min}$ provides similar fire protection efficiency as the coating of sample No. 1 with a thickness of $50 \mathrm{~mm}$ and a section ratio of $294 \mathrm{~mm}^{-1}$ and sample No. 2 with a thickness of $20 \mathrm{~mm}$ and a section ratio of $172 \mathrm{~mm}^{-1}$, subjected to conditions of the hydrocarbon burning regime without cryogenic influence (Table 2). Sample No. 3.2 with a dry layer thickness of $30.9 \mathrm{~mm}$ after cryogenic testing for $60 \mathrm{~min}$ provides a time of reaching a critical temperature of $+500{ }^{\circ} \mathrm{C}$ in the sample for at least $120 \mathrm{~min}$.

Table 2. Comparison of initial data and obtained results of fire retardant coatings based on STBF.

\begin{tabular}{|c|c|c|c|}
\hline $\begin{array}{c}\text { Parameters/Names of Flame } \\
\text { Retardant Coatings }\end{array}$ & Sample No. 1 & Sample No. 2 & $\begin{array}{c}\text { Sample No. } 3.1 / \text { Sample No. } \\
3.2\end{array}$ \\
\hline Tested samples & I-section column No.20B1 & I-section column No.50B2 & I-section column No.50B2 \\
\hline $\mathrm{A}_{\mathrm{p}} / \mathrm{V}, \mathrm{mm}^{-1}$ & 294 & 172 & 170 \\
\hline $\begin{array}{l}\text { Thickness of dry layer of fire } \\
\text { retardant, mm }\end{array}$ & 50 & 20 & $20.6 / 30.9$ \\
\hline Presence of cryogenic test & no & no & yes \\
\hline Cryogenic test time, $\min$ & - & - & $\begin{array}{c}60 \text { (without reaching critical } \\
\text { temperature) }\end{array}$ \\
\hline $\begin{array}{c}\text { Moment of the start of the fire } \\
\text { test }\end{array}$ & $\begin{array}{c}\text { as the sample is ready and the } \\
\text { furnace is prepared }\end{array}$ & $\begin{array}{l}\text { as the sample is ready and the } \\
\text { furnace is prepared }\end{array}$ & $2.5 \mathrm{~h}$ after cryogenic test \\
\hline Fire regime & hydrocarbon & hydrocarbon & hydrocarbon \\
\hline Fire protection efficiency & 90 & 90 & $90 / 147$ \\
\hline
\end{tabular}


Fire tests of the experimental samples were conducted in accordance with $[35,36]$ under the condition of creating a hydrocarbon temperature regime in the furnace according to [10], thereby by the plotted graphs we can say about the character of the curve growth (Figure 6).

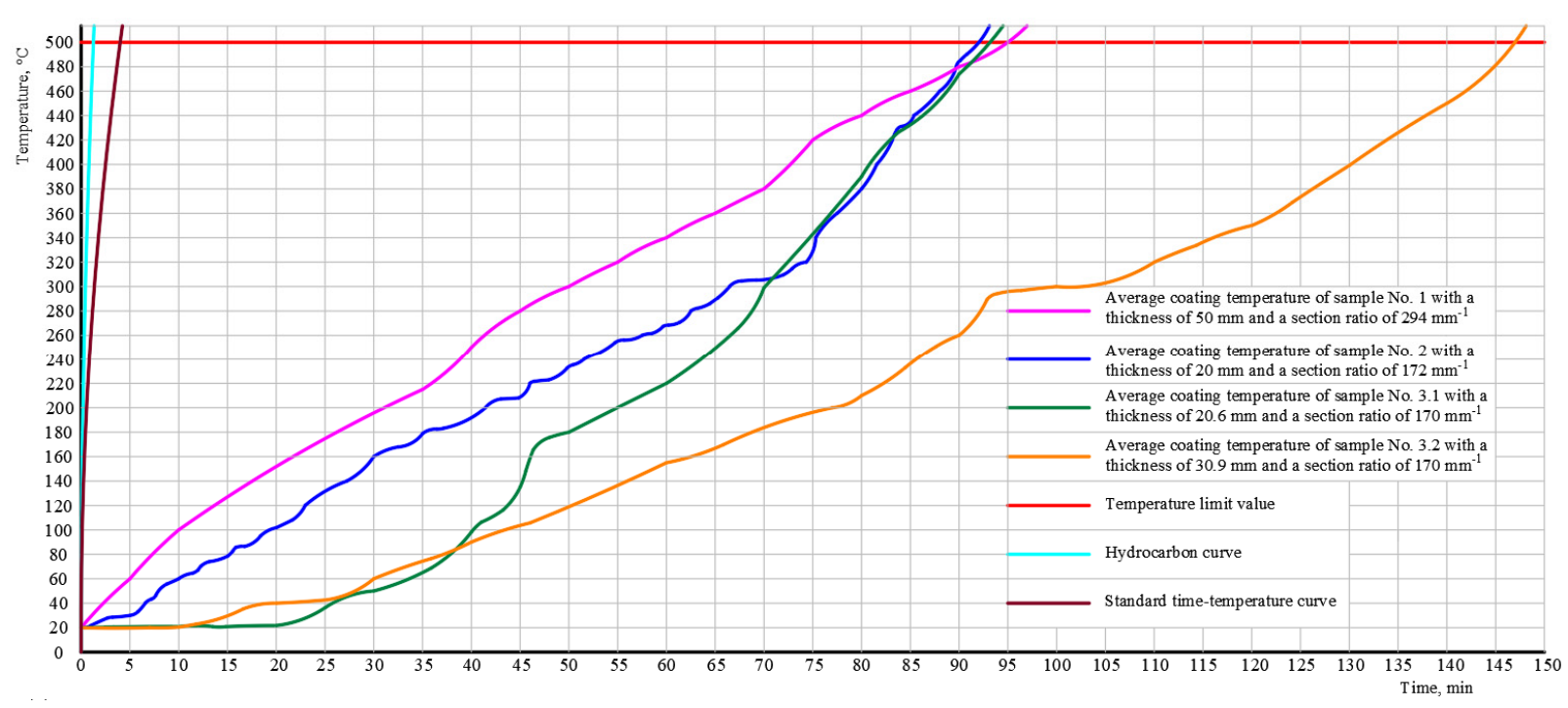

Figure 6. Temperature changes on the samples during the fire test.

In the process of fire testing the flame retardant coating of sample No. 1, a smooth increase in temperature is observed during the first minutes of the test with a subsequent "linear" increase practically during all phases of the test, while with sample No. 3.2 with material thickness $30.9 \mathrm{~mm}$ during the first $12 \mathrm{~min}$, there was almost no temperature change. Moreover, with sample No. 3.1 with material thickness $20.6 \mathrm{~mm}$ during $21 \mathrm{~min}$, as the heat absorption process takes place, then a faster heating begins, as a result of which the given fire protection product approaches samples No. 1 and 2 for 90 min.

Since the tests were conducted on columns with different section ratios, a direct comparison according to Figure 6 will not be quite correct. Let's consider a diagram of multifactor analysis of these flame retardants as a function of technological, operational, and cost parameters, and express these dependencies as histograms (Figure 7). The following parameters were taken into account: fire protection efficiency at hydrocarbon and standard temperature conditions (R90 HC, R90), frost resistance, structural load, service life over 25 years, corrosion resistance, vibration resistance, adhesion to the substrate, resistance to weather conditions, maintainability, and cost. Let's assume that the evaluation of fire protection means will be expressed in relative units (points) from 1 (low score) to 5 (high score).

So, structural protection with an endothermic effect presents the best rates of fire protection efficiency and does not concede other indicators of structural fire protection based on STBF, but at the same time it is significantly more expensive than its counterparts. Since the fire protection products considered in this article are planned to operate in the conditions of the Arctic and Antarctic, it is obvious that plaster compositions and epoxy coatings, as materials of a "wet process", are not suitable for such tasks. In turn, epoxy coatings are not non-combustible materials, unlike plaster compositions and structural protection. 


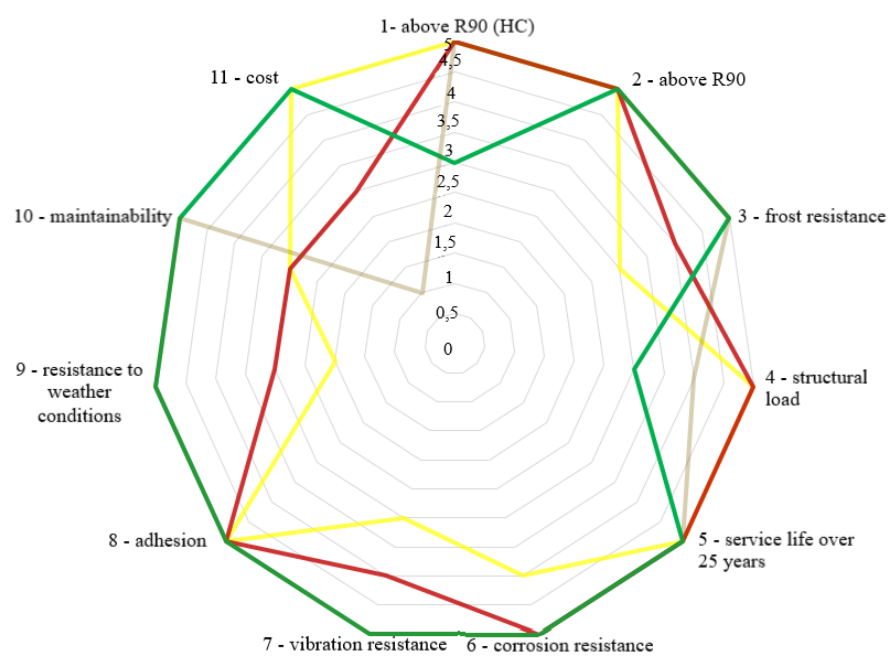

(a)

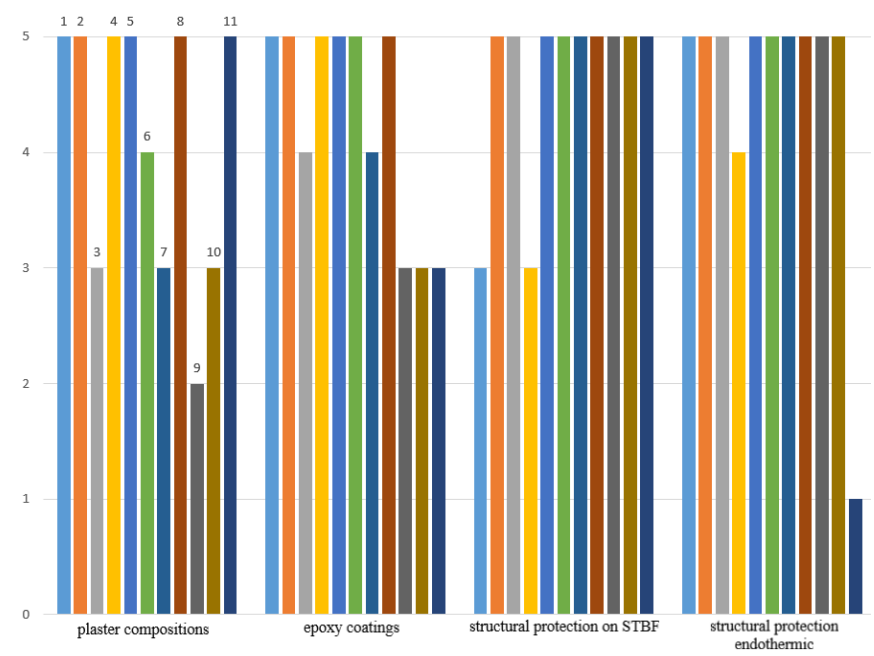

(b)

Figure 7. (a) Diagram and (b) histograms for different types of fire protection (red-epoxy coatings, green—structural protection on STBF, yellow-plaster compositions and gray—structural protection endothermic).

\section{Conclusions}

Nowadays, in connection with the expansion of the world oil and gas industry in the Arctic and Antarctic, the problem with the protection of steel structures of buildings under hydrocarbon fire conditions, including after cryogenic spillage of liquefied hydrocarbons, is apparent. Over the past five years, the design of steel structures with increased fire resistance limits has been regulated by international and industry standards of oil and gas facilities, which impose requirements on fire protection means for steel structures in terms of resistance to cryogenic effects of cryogenic liquids and tests under a hydrocarbon fire regime. There are not many studies devoted to this topic due to its relative novelty. Developments in the field of fire protection of steel structures under arctic climate conditions are expected.

According to the results of the study, the most effective means of fire protection of steel structures in the Arctic and Antarctic are materials based on STBF, providing a "dry" method of installation, long operating time in severe conditions, resistance to the cryogenic spillage of liquefied hydrocarbons and a hydrocarbon fire regime.

Author Contributions: Conceptualization, M.G.; data curation, D.S. All authors have read and agreed to the published version of the manuscript.

Funding: This research received no external funding.

Institutional Review Board Statement: Not applicable.

Informed Consent Statement: Not applicable.

Data Availability Statement: Testing laboratories of the Federal State Budgetary Institution VNIIPO of the Ministry of Emergency Situations, "POZH-AUDIT" and "Ognestoykost».

Conflicts of Interest: The authors declare no conflict of interest.

\section{References}

1. ACIA. Arctic Climate Impact Assessment; Cambridge University Press: Cambridge, UK, 2005; p. 1072.

2. Gravit, M.; Golub, E.; Klementev, B.; Dmitriev, I. Fire Protective Glass Fiber Reinforced Concrete Plates for Steel Structures under Different Types of Fire Exposure. Buildings 2021, 11, 187. [CrossRef]

3. Kim, J.H.; Baeg, D.Y.; Seo, J.K. Numerical Investigation of Residual Strength of Steel Stiffened Panel Exposed to Hydrocarbon Fire. J. Ocean. Eng. Technol. 2021, 35, 203-215. [CrossRef]

4. Imran, M.; Liew, M.S.; Nasif, M.S.; Niazi, U.M.; Yasreen, A. Hazard Assessment Studies on Hydrocarbon Fire and Blast: An Overview. Adv. Sci. Lett. 2017, 23, 1243-1247. [CrossRef] 
5. ISO 20088-1:2016. Determination of the Resistance to Cryogenic Spillage of Insulation Materials—Part 1: Liquid Phase. Available online: https:/ / www.iso.org/ru/standard/67009.html (accessed on 21 August 2021).

6. ISO 20088-2:2020. Determination of the Resistance to Cryogenic Spill of Insulation Materials_Part 2: Vapour Exposure. Available online: https:/ / www.iso.org/ru/standard/67010.html (accessed on 21 August 2021).

7. ISO 20088-3:2018. Determination of the Resistance to Cryogenic Spillage of Insulation Materials-Part 3: Jet Release. Available online: https: / www.iso.org/ru/standard/67011.html (accessed on 21 August 2021).

8. UL 1709. Rapid Rise Fire Tests of Protection Materials for Structural Steel. Available online: http:/ / nd.gostinfo.ru/print.aspx? control=27\&id=4546871\&print=yes (accessed on 24 August 2021).

9. Russian Government Standard GOST 1363-2-2014. Fire Resistance Tests. Alternative and Additional Procedures. Available online: https:/ / docs.cntd.ru/document/1200113419 (accessed on 8 August 2021).

10. EN 1363-2:1999. Fire Resistance Tests-Part 2: Alternative and Additional Procedures. Available online: https://nd.gostinfo.ru/ document/6239985.aspx (accessed on 10 August 2021).

11. Gravit, M. Modeling and standardization of flame retardants for hydrocarbon fire regime. J. Coat. Sci. Technol. 2020. Available online: https:/ / www.lkmportal.com/articles/modelirovanie-i-standartizaciya-sredstv-ognezashchity-dlya-uglevodorodnogorezhima-pozhara (accessed on 15 August 2021).

12. Reid, M. The Piper Alpha Disaster: A Personal Perspective with Transferrable Lessons on the Long-Term Moral Impact of Safety Failures. ACS Chem. Health Saf. 2020, 27, 88-95. [CrossRef]

13. Zybina, O.; Gravit, M. Intumescent Coatings for Fire Protection of Building Structures and Materials; Springer Series on Polymer and Composite Materials; Springer International Publishing: New York, NY, USA, 2020; Volume XI, p. 210. ISBN 978-3-030-59422-0. [CrossRef]

14. McClain, C.R.; Nunnally, C.; Benfield, M.C. Persistent and substantial impacts of the Deepwater Horizon oil spill on deep-sea megafauna. R. Soc. Open Sci. 2019, 6, 1-9. [CrossRef] [PubMed]

15. Evangelista, H.; Sodré, E.D.; Castagna, A. Preliminary Investigation on the Atmospheric Dispersion of Pollutants Due to Ferraz Fire. INCT-APA Annu. Act. Rep. 2013, 35-42. [CrossRef]

16. Hassel, M.; Utne, I.B.; Vinnem, J.E. Allision risk analysis of offshore petroleum installations on the Norwegian Continental Shelf-an empirical study of vessel traffic patterns. WMU J. Marit. Aff. 2017, 16, 175-195. [CrossRef]

17. Li, J.; Hao, H. Internal and external pressure prediction of vented gas explosion in large rooms by using analytical and CFD methods. J. Loss Prev. Process. Ind. 2017, 49, 367-381. [CrossRef]

18. Abramov, I.; Gravit, M.; Gumerova, E. Increase in the Fire Resistance Limits of Ship and Building Structures with HydroCarbon Fire. GAS Industry; (Gazovaya promyshlennost'); No 5. 2018, pp. 108-117. (In Russian). Available online: https: //www.neftegas.info/upload/iblock/cf0/cf0b020575328defe0b0961c2c0c4e0b.pdf (accessed on 15 August 2021).

19. Fireproofing for Hydrocarbon Fire Exposures / / GAPS Guidelines. Publication of Global Asset Protection Services LLC. Available online: https:/ / www.appliedbuildingtech.com/system/files/gap2.5.1.fireproofingforhydrocarbonexposures.pdf (accessed on 24 August 2021).

20. Palazzi, E.; Fabiano, B. Analytical modelling of hydrocarbon pool fires: Conservative evaluation of flame temperature and thermal power. Process. Saf. Environ. Prot. 2012, 90, 121-128. [CrossRef]

21. Cirpici, K.B.; Wang, Y.C.; Rogers, B.D. An analytical approach for predicting expansion of intumescent coating with different heating conditions. In Proceedings of the 12th International Congress on Advances in Civil Engineering, Istanbul, Turkey, 21-23 September 2016; pp. 1-8.

22. Hiroya, Y.; Tanabe, M.; Kataoka, S.; Yamada, Y.; Miyashita, T. Simplified Method to Define the Cryogenic Spill Hazard in LNG Liquefaction Facility. Chem. Eng. Trans. 2019, 77, 505-510. [CrossRef]

23. Hiroya, Y.; Tanabe, M.; Kataoka, S.; Yamada, Y.; Miyashita, T. Optimization of cryogenic spill protection insulation thickness. Chem. Eng. Trans. 2016, 48, 643-648. [CrossRef]

24. Mikalsen, R.F.; Glansberg, K.; Wormdahl, E.D.; Stolen, R. Jet fires and cryogenic spills: How to document extreme industrial incidents. In Proceedings of the Sixth Magdeburg Fire and Explosion Days conference proceedings, Magdeburg, Germany, 25-26 March 2019; pp. 1-6.

25. UL 263. Fire Tests of Building Construction and Materials. Available online: https://standardscatalog.ul.com/ProductDetail. aspx?productId=UL263 (accessed on 24 August 2021).

26. UL 1724. Investigation for Fire Tests for Electrical Circuit Protective Systems. Available online: https://standards.globalspec com/std/260679/UL\%201724\%20OUTLINE (accessed on 24 August 2021).

27. Akaa, O.; Abu, A.; Spearpoint, M.; Giovinazzi, S. Optimising design decision-making for steel structures in fire using a hybrid analysis technique. Fire Saf. J. 2017, 91, 532-541. [CrossRef]

28. Eremina, T.; Korolchenko, D. Fire Protection of Building Constructions with the Use of Fire-Retardant Intumescent Compositions. Buildings 2020, 10, 185. [CrossRef]

29. Oliveira, R.B.R.; Junior, L.C.M.V.; Vieira, L.C.M. Intumescent paint as fire protection coating. Rev. IBRACON Estrut. Mater. 2017, 10, 220-231. [CrossRef]

30. Gravit, M.V.; Golub, E.V.; Antonov, S.P. Fire protective dry plaster composition for structures in hydrocarbon fire. ICE Pro-Ceedings Civ. Eng. 2018, 3. [CrossRef] 
31. Rivera, M.M.; Vaz, M.A.; Julio, C.; Cyrino, R.; Landesmann, A. A study on the use of PFP in off-shore topside structures subject to localised fires. In Proceedings of the 28th International Congress on Waterborne Transportation, Shipbuilding and Offshore Constructions, Rio de Janeiro, Brazil, 26-29 October 2020. [CrossRef]

32. Park, D.K.; Kim, J.H.; Park, J.S.; Ha, Y.C.; Seo, J.K. Effects of the structural strength of fire protection insulation systems in offshore installations. Int. J. Nav. Arch. Ocean. Eng. 2021, 13, 493-510. [CrossRef]

33. Kremnev, V.; Basok, B.; Timoshchenko, A.; Tymchyshyn, S. Energy Saving in Construction by Wide Application of High-Quality Insulation Based on Basalt Fibers. J. Mod. Phys. 2018, 9, 1724-1734. [CrossRef]

34. Russian Federal Law No. 123-FZ. Technical Regulation of Fire Safety. Available online: http://www.consultant.ru/document/ cons_doc_LAW_78699/ (accessed on 25 August 2021).

35. ISO 834-1:1999. Fire-Resistance Tests-Elements of Building Construction-Part 1: General Requirements. Available online: https:/ / www.iso.org/standard/2576.html (accessed on 24 August 2021).

36. Russian Government Standard GOST 53295-2009. Fire Retardant Compositions for Steel Constructions. General Requirement. Method for Determining Fire Retardant Efficiency. Available online: https:/ /docs.cntd.ru/document/1200071913 (accessed on 28 August 2021).

37. Russian Government Standard GOST 57837-2017. Hot-Rolled Steel I-Beams with Parallel Edges of Flanges. Specifications. Available online: https:/ / docs.cntd.ru/document/1200157342 (accessed on 28 August 2021).

38. Eurocode 3: Design of Steel Structures-Part 1-2: General Rules Structural Fire Design. Available online: https://www.phd.eng. br/wp-content/uploads/2015/12/en.1993.1.2.2005.pdf (accessed on 10 September 2021). 